Language

Te^

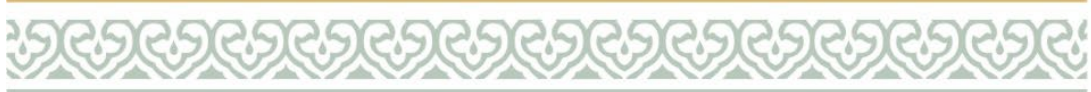

язык

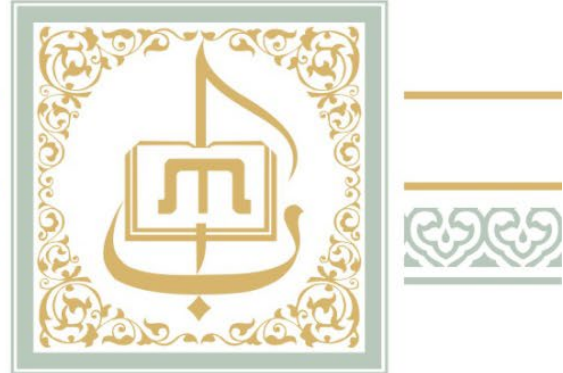

DOI: 10.26907/2311-2042-2019-13-2-7-17

\title{
THE FIRST AND SECOND PERSON AFFIXES IN POSSESSIVE CONSTRUCTIONS OF THE TATAR, BASHKIR AND CHUVASH LANGUAGES: FREQUENCY OF USE
}

\author{
Khisiyama Yuto, \\ 3-11-1, Futu-se, Asahi-te, Tokyo, 183-8534, Japan, \\ boltwatts@gmail.com.
}

Guzel Amirovna Nabiullina, Kazan Federal University, 18 Kremlyovskaya Str., Kazan, 420008, Russian Federation, guzelnab2@yandex.ru.

The category of possessiveness is a specific grammatical category typical of Turkic languages. However, as indicated in Turkic studies, in some Turkic languages, including Tatar, Bashkir, and Chuvash, the possessive affix is optional if the possessive construction includes the pronoun of the I or II person: минем дәфтәр (ем), синең дәфтәр (ең), безнең дәфтәр (ебез), сезнең дәфтәр (егез).

The main purpose of this paper is to analyze the frequency of use of possessive endings in Turkic languages, in particular, in Tatar, Bashkir, and Chuvash. The research shows that in all three languages the frequency of possessive endings depends on the person and the number. The affix of possessiveness of the first person plural is most often found in these languages, and the possessive affix of the second person singular has the lowest frequency. In our opinion, two factors account for this linguistic phenomenon: 1) the number of persons indicated by the personal pronoun; 2) the length of the possessive ending.

Key words: Tatar language, Bashkir language, Chuvash language, possessive category, possessive endings.

The category of possessiveness is a specific grammatical category typical of Turkic languages. Usually this category indicates that the item belongs to a person. It has special endings called possessive endings. In Tatar, for example, the possessive endings are the following: $-\boldsymbol{M} /-\boldsymbol{b l} \boldsymbol{M} / \boldsymbol{- e \boldsymbol { M }}$, -ц/-ыңң/-ең, -сыl/-се/-ыl/е, -ыббыз/-ебез/-быз/-без, -ыгыз/-егез/-гыз/-гез, -лары/-ләре/-нары/-нәре.

Initial information about the possessive category in Turkic linguistics is found in the grammars of the $19^{\text {th }}$ century. The possessive category, its endings, and meanings are studied in detail in Turkic 
grammars and research works written in the early $20^{\text {th }}-21^{\text {st }}$ centuries. In Tatar linguistics, the ways of denoting the possessive category are described in the works of G. Alparov (1926), V. Hangildin (1959), Z. Valiullina, K. Zinnatullina, M. Sagitov (1972), D. Tumasheva (1978), M. Zakiev (1993), F. Khisamova (2006), and Ch. Kharisova (2010). $\mathrm{V}$. Hangildin notes that the possessive forms of the first and second persons can enter into a syntactic relationship only along with personal pronouns. He underlines that the endings of the modified word have specific contracted pronunciation of personal pronouns in the genitive case and phrases with nouns having possessive endings [Hangildin, $p$. 80]. According to V. Hangildin, possessive endings of the III person, in contrast to the endings of the I and II persons, may refer both to the person and to another object. As the concept of the possessive form of the third person is broad and undefined, it should always be designated. Therefore, contacted forms of endings and attributes are rarely used. [Hangildin, p. 80, p. 81].

The grammar book, compiled by Z. Valiullina, K. Zinnatullina, and M. Sagitov, shows the use of the category of possessiveness of the I and II persons in three forms, where the object or the person applies only to a person (the first and the second person) [Valiullina, Zinnatullina, Sagitov, p. 53]. The authors note the impossibility to use the third person without an ending (in its analytical form) due to the fact that the third person is mainly modified by a personal pronoun or noun. As a result, the analytical method is not used at all, and the synthetic method is extremely rare [Valiullina, Zinnatullina, Sagitov, p. 53].

Although D. Tumasheva's research does not show the ways of expressing the category of possessiveness, it explains the possessiveness of the endings attached to the noun, to the person. The researcher emphasizes the possibility of expressing these categories by just one word in the I and II persons (минем китап, синең китап, безнең, бакча, сезнең бакча), underlining the use of the analytical forms of the category [Tumasheva, $p$. 46].

In grammar books by M. Zakiev, the forms of possessiveness are shown explicitly and the peculiarities of each form are indicated. There are three methods indicated by the forms of possessiveness of the I and II persons: synthetic, analytical, and analytical-synthetic methods [Zakiev, p. 32, p. 33]. Considering the features of use of every method one can see that the first (synthetic) method is equally used in oral and written speech, the second (analytical) method is used more in oral speech, and the third (analytical-synthetic) method is more often used in written speech. According to the researcher, the third method is characterized by emotionality. The rearrangement of words in phrases leads to increased emotionality [Zakiev, p. 32, p. 33]. Two methods are highlighted for the form of the third person possessiveness: synthetic and analytical-synthetic, and in the case of the synthetic method, it is shown to whom (or to what) the object belongs [Zakiev, p. 33].

The works of F. Khisamova and Ch. Kharisova indicate three structural types and determine the value of possessiveness: synthetic, analyticalsynthetic, and analytical methods. The forms of possessiveness of the I and II persons are used in three types, though the drop-off of the possessive ending of the III person in the modern Tatar language is defined as a discrepancy to the literary norm [Kharisova, p. 20, p. 21].

In the Bashkir language linguistics, the ways of expressing the category of possessiveness are thoroughly studied in the works of N. Dmitriev (1948), A. Yuldashev (1981), and M. Zainullina (2002). In addition to the main type of the category of possessiveness (am-blм, am-blh, am-bl), N. Dmitriev identifies and describes the existence of two more types (минем атым һәм һинең ат) belonging to the same category. Categorizing the second type as "morphological-syntactic" (минең атым), and the third - "syntactic" (минен am), he points out that the structure of the category of possessiveness is similar to the form of its expression in Russian and German (мой конь, mein Pferd) [Dmitriev, p. 58]. The author notes that the frequency of use of these types lies not only in the field of grammar, but also in the field of stylistics. According to N. Dmitriev, the main semantic stress in the word amblм falls on the noun am, and the repeated use of the concept минекелек "being mine" in the phrase минен amblм adds certain feelings and emotions [Dmitriev, p. 58]. The form "Минең ат" is found in Turkic written monuments of the $8^{\text {th }}$ century, thus, the researcher believes that the formation of this pattern was not influenced by the Russian language [Dmitriev, p. 58].

A. Yuldashev (1981) identifies two ways of determining possessiveness: in the I and II persons it is expressed by means of a personal pronoun in the genitive case and by adding the ending of possessiveness: минең илем, иинең илең. The meaning of possessiveness is also expressed by the lexicalsyntactic method, that is, by the personal pronoun in the genitive case: минең малай, һинең малай, 
без̧зец малай, һез̧зең малай [Iuldashev, p. 123]. The use of a noun with the possessive ending together with a personal pronoun in the genitive case, indicating that an object belongs to a given person, helps to express emotions. For example: Был күл минең һарайым, Көн дә коштай койонам (folklore); Күккә ашкан Уральым, Минең изге төйәгем, һез̧зе һөйа йөрагем (S. Yulaev) [Iuldashev, p. 123]. In contrast to the I and II persons, the possessive form of the III person is always formed with the possessive ending, regardless of the presence or absence of the specified

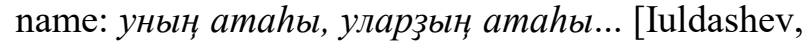
p. 123]. The author also pays attention to the fact that the change in the order of words in the possessive patterns of the singular I and II persons affects emotionality: Йөрәккәйем минең әллә нишләй, Acыл карар инем, аскыс юк (folklore) [Iuldashev, p. 123].

In M. Zainullina's grammar (2002), three main types of the category of possessiveness in nouns are mentioned: the type formed by adding the endings to nouns is called "a morphological type" (китаб-ылм, китаб-ың, китаб-ыз; алма-быз, алма-выз, алма-лары). The type formed with the help of the endings, consisting of personal pronouns indicating the possessor and the name itself denoting the possessed object, is called "a morphological syntactic form" (минең китаб-ьым, һинең китаб-ың, уныңң китаб-ыл; без̧зең алма-бызз, һез̧зең алма-выз, уларзың алма-лары). If personal pronouns, indicating the possessor, are used in the genitive case and the name itself, denoting the possessed object, is used without any endings - this type is called syntactic (минең китап, һинең китап, без̧зең китап, һез̧зең китап) [Zainullin, p. 21].

The designation of the category of possessiveness in Chuvash is explained in the works of $\mathrm{J}$. Krueger (1961), L. Sergeev, E. Andreeva, and V. Kotleev (2012). According to J. Krueger, there are three methods denoting the category of possessiveness in Chuvash [Krueger, p. 113, p. 116]. The first method is similar to the English words "my, our, your..", this method is formed by personal pronouns in the genitive case: манӑн лама (my horse), санӑн лаша (your horse), унӑн лаши (his horse), пирӗн лаша (our horse), сирён лаша (your horse), вёсен лаши (their horse) [Krueger, p. 113]. Krueger notes that this way of expressing the category of possessiveness is often used in the Chuvash language. The researcher pays attention to another method found in other Turkic languages: the method of applying a special ending to show who the owner of the possession is. For example: ьввӑл-ӑм (ул-ым) [my son], ьөвӑл-y (ул-ың) [your son], вьвӑл-ӗ (ул-ы) [his son], ьввӑл-ӑмӑр (улыбыз) [our son], вьвӑл-ӑр (ул-ыгыз) [your son], ылвӑл-ё (ул-ы) [their son] [Krueger, p. 116]. Не explains that if it is necessary to determine the ownership of the subject, the above two methods are considered together in the synthesis. This method is used to form a certain accent, as in the English sentence "Our son did this, but their son did that": манӑн вьвӑл-ӑм (минем ул-ым), санӑн ывӑл-y (синең ул-ың), унӑн ыввӑл-ё (аның ул-ы), пирӗн ывӑл-ӑмӑр (безнең ул-ыбыз), сирён ыввӑлăp (сезнең ул-ыгыз), вӗсен ывӑл-ӗ (аларның улы) [Krueger, p. 113, 116]. According to Krueger, in the plural forms of the I and II persons, the analytical construction is used more often in Chuvash today. For example, instead of вьвӑл-ӑмӑр - пирён ьввӑл is used, instead of вьвӑл-ӑр - сирён ьввӑл-y is used [Krueger, p. 118].

The relation of an object to a person in $\mathrm{L}$. Sergeev's work is denoted in two ways:

1) the use of words before a noun denoting possession (syntactic method), i.e. personal pronouns (манӑн, пирён, санӑн, сирён, унӑн, вёсен). For example: манӑн ручка (моя ручка) [my pen], пирён ручка (наша ручка) [our pen], сирён кёнеке (ваша книга) [your book], унӑн ручки (его ручка) [his pen], вӗсен кеинеки (их книга) [their book];

2) if an item belongs to someone, it can be expressed in a morphological way, i.e. with the help of special endings. These endings are called affixes of possession (Chuvash. камӑнлӑх аффиксёсем). For example: сётел-ём (өстәл-ем) [my table], сётел-y" (өстәл-ең) [your table], сётел-ё (өстәл-е) [his table] [Sergeev, p. 266, p. 267]

According to L. Sergeev, the endings of possession of the I and II persons in Chuvash are used very rarely: the I person possession is expressed more widely by the context, not by means of endings. For example, кус курмасть (күз күрми) [еуе doesn't see]. In this example the belonging of the eyes to the I person can be understood through the context, which explains the rare use of the endings in this case [Sergeev, p. 270]. The belonging of an item to any person can be expressed in a mixed way: санӑн (хӑвӑн) кӗнек-у゙ (синең (үзеңнең) китаб-ың) [your own book], пирӗн (хамӑрӑн) учител-ӗмёр (безнең (үзебезнең) укытучы-быз [our own teacher]. But these constructions refer to literary language and are rarely found in spoken language [Sergeev, p. 272]. The III person, unlike 
other forms, always attaches the ending of the possessive category: (унӑн) тетрач-ӗ ((аның) дәфтәр-е)[his (own) copybook], (вёсен) пуррч-ӗ ((аларның) йорт-ы) [their house], (хӑйён) лам-и ((үзенең) ат-ы)[his (own) horse] [Sergeev, p. 272].

As you can see, the constructions of the category of possessiveness are well studied in the grammars of the Tatar, Bashkir, and Chuvash languages. Turkologists have proved that the use of constructions with the possessive category is characteristic of written speech. They also note that oral speech is not characterized by the use of the possessive categories. Thus, the theoretical studies demonstrate that the category of possessiveness, its features, its use and types are sufficiently studied in Turkic linguistics. However, there are also insufficiently covered questions: for example, the frequency of use of certain structural types of the possessive categories, the paradigm of their use, their grammatical nature, stylistic features - which have not been properly studied. Taking into account these features, the main purpose of this work is to determine the frequency of use of the possessive category endings in Turkic languages: in Tatar, Bashkir, and Chuvash. In this article we explore the forms of possessive categories of the I and II persons in the Tatar, Bashkir, and Chuvash languages. The subject under study is the personal pronouns of the I or II persons in the genitive case, as well as the phrases consisting of nouns without the category of possessiveness or nouns with the category of possessiveness in the Tatar, Bashkir, and Chuvash languages. When studying the frequency of use of the possessive category endings we employed the statistical method, when analyzing the research results, comparative and descriptive methods were applied. We based our study on the following online corpora:

1) The Written Corpus of the Tatar Language. The volume of the corpus is currently more than 356 million words [http://corpus.tatfolk.ru/ index_tt.php].

2) The Corpus of Bashkir Poetry. Includes more than 1 million words, about 500 thousands poetic lines, more than 13000 poems by 101 writers [http://web-corpora.net/bashcorpus/search/].

3) Чӑваш чӗлхин икчёлхеллӗ суйпс̧и (Тhe Bilingual Corpus of the Chuvash Language). More than 1 million words recorded. Basically, the corpus contains newspaper-magazine and religious informative articles [http://corpus.chv.su/].

According to the results of the analysis of the corpus data, we have revealed the following trends in the frequency of use of affixes belonging to the I and II persons in the Tatar, Bashkir, and Chuvash languages:

1) 1000 constructions from "The Written Corpus of the Tatar Language" with the possessive category were selected for the I and II person pronouns. Thus, we have made conclusions about the frequency of use of constructions with and without affixes:

$\begin{array}{lcc} & \text { without affixes } & \text { with affixes } \\ \text { 1 person singular } & 91(36.4 \%) & \mathbf{1 5 9}(\mathbf{6 3 . 6 \% )} \\ \text { 1 person plural } & \mathbf{2 0 9}(\mathbf{8 3 . 6 \%}) & 41(16.4 \%) \\ 2 \text { person singular } & 51(20.4 \%) & \mathbf{1 9 9}(\mathbf{7 9 . 6 \% )} \\ 2 \text { person plural } & \mathbf{1 3 4}(\mathbf{5 3 . 6 \% )} & 116(46.4 \%)\end{array}$

2) 200 constructions from "The Corpus of Bashkir Poetry" with the possessive category were selected for the I and II person pronouns. Thus, the following results have been obtained concerning the frequency of use of constructions with and without affixes:

$\begin{array}{lcc} & \text { without affixes } & \text { with affixes } \\ \text { 1 person singular } & 20(40.0 \%) & \mathbf{3 0}(\mathbf{6 4 . 0 \%}) \\ \text { 1 person plural } & \mathbf{4 5}(\mathbf{9 0 . 0 \%}) & 5(10.0 \%) \\ 2 \text { person singular } & 8(16.0 \%) & \mathbf{4 2}(\mathbf{8 4 . 0 \% )}) \\ 2 \text { person plural } & \mathbf{3 3}(\mathbf{6 6 . 0 \% )} & 17(34.0 \%)\end{array}$

3) 200 constructions from "The Bilingual Corpus of the Chuvash Language" ("Чӑваш чӗлхин икчӗлхеллё суйпс̧и") have been selected for the I and II person pronouns with the category of possessiveness. The frequency of use of constructions with and without affixes of belonging is as follows:

1 person singular without affixes with affixes

1 person plural $42(84.0 \%) \quad 8(16.0 \%)$

2 person singular $49(98.0 \%) \quad 1(2.0 \%)$

2 person plural $13(26.0 \%) \quad 37(\mathbf{7 4 . 0 \%})$ $31(62.0 \%) \quad 19(38.0 \%)$

Having analyzed the materials of the corpora and the forms of the possessive category of the genitive case in the Tatar and Bashkir languages, we have revealed the difference in the frequency of use of these two forms. In constructions with personal singular pronouns in both languages, the analytical form is found less frequently than the analytical-synthetic form. And vice versa, in constructions with personal plural pronouns, the analytical form is used more often than the analyticalsynthetic one. The main reason for this is probably the fact that the plural form of personal pronouns 
has long endings and in the process of speech it tends to be simplified. When comparing these two persons, we have come to the conclusion that the use of the analytical form in the I person is more vivid than the use of the analytical form in the II person. Even if the frequency of use of the two forms differs slightly depending on the style of speech, there are no major differences in the general trends outlined above. We believe that it is impossible to determine the frequency of use of the two forms only based on the styles of speech or its emotionality, as stated in the grammar. It should be noted that the form varies depending on the construction of the possession and the type of noun in the possessiveness construction. As we see, in all three languages the frequency of use of possessive pronoun endings differs depending on the person and the number. And in all three languages the ending of possessive pronouns of the I person plural is used less often, while the ending of the possessive pronoun of the II person singular is most common. It is noteworthy that all three languages share common trends.

Looking at the results, we can say that the frequency of use of the possessive category is influenced by the following factors:

1) plurality, expressed by personal pronouns. In all three languages the II person pronoun in plural (тат. сез, баш. hез̧, чув. эсир) can express only one person. The I person plural (тат. без, баш. без, чув. эпир) always denotes two or more people. Therefore, if the person expressed by the personal pronoun is used in the plural the use of the possessive ending may be rare. This factor does not concern Chuvash, because in this language the frequency of using possessive endings of the I person singular is less common than that of the II person plural.

2) completeness / brevity of possessive endings. Based on the principle of economy complete endings of the possessive category can be omitted. In the Tatar and Bashkir languages, plural endings (тат. -(bl)быз/-(e)без, -(bl)гыз/-(e)гез; баш. -

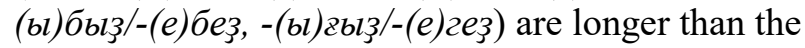
endings of the singular form $\left(-(b l)_{\mathcal{M}} /-(e)_{\mathcal{M}},-(b l)_{\eta} /-\right.$ (e) $y_{3}$. In the Chuvash language, possessive endings

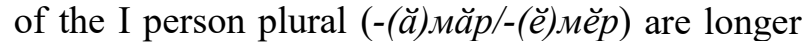
than other endings $\left.(\breve{a})_{\mathcal{M}} /-(\breve{e})_{\mathcal{M}},-y /-\bar{y}, \quad-(\breve{a}) p /-(\breve{e}) p\right)$. Nevertheless, the issue of rare use of short forms of the possessive category endings in Chuvash remains open.

In conclusion, we can say that the frequency of the possessive ending use differs depending on its number and person: the I person plural endings are rarely used in three languages, while the II person singular endings are used more often.

In our opinion, two factors contribute to this phenomenon: 1) the plurality of the person expressed by the personal pronoun; 2) the completeness / brevity of the endings of the category of possessiveness. The possibility of other reasons is not excluded. The clarification of such issues and a comparative analysis of this trend in other Turkic languages is our upcoming task.

\section{References}

Dmitriev, N. K. (1948). Grammatika bashkirskogo iazyka [Grammar of the Bashkir Language]. 276 p. AN SSSR. Moscow. (In Russian)

Hishiiama, Y. (2019). Possessive Person Markings in Tatar Possessive Noun Phrases. Language, Area and Culture Studies. Pp. 93-113. Tokyo, Tokyo University of Foreign Studies. (In English)

Iuldashev, A. A. (1981). Grammatika sovremennogo bashkirskogo literaturnogo iazyka [Grammar of the Modern Bashkir Literary Language]. 495 p. Moscow, Nauka. (In Russian)

Khangildin, V. N. (1959). Tatar tele grammatikasy [Grammar of the Tatar Language]. 642 p. Kazan, Tatarstan kitap nəshriyat. (In Tatar)

Kharisova, Ch. M. (2010). Khazerge tatar adabi tele morfologiyasennan lektsiyalor [Lectures on the Morphology of the Modern Tatar Literary Language]. 128 p. Kazan, Tatar dəylət gumanitar-pedagogika universitety. (In Tatar)

Khisamova, F. M. (2006). Tatar tele morfologiyase [Morphology of the Tatar Language]. 335 p. Kazan, Məgarif nəshriyaty. (In Tatar)

Krueger, J. (1961). Chuvash Manual. Introduction, Grammar, Reader, and Vocabulary. Indiana University Publications, Uralic and Altaic Series 7. 271 p. The Hague, Mouton. (In English)

Sergeev, L. P., Andreeva, Ye. A., Kotleev, V. I. (2012). Chăvash chĕlkhi: chăvash filologi fakul'techĕn studenchěsem valli khatěrleně věrenü këneki. $431 \mathrm{p}$. Shupashkar, Chăvash kĕneke izd-vi. (In Chuvash)

Tumasheva, D. G. (1978). Khazerge tatar adabi tele: Morfologiia [Modern Tatar Literary Language].

221 p. Kazan, Tatarstan kitap nəshriiaty. (In Tatar)

Vəliullina, Z. M., Zinnətullina, K.Z., Səgyitov, M. A. (1972). Khazerge tatar adabi tele morfologiyase [Morphology of the Modern Tatar Literary Language]. 206 p. Kazan, KDPI. (In Tatar)

Zakiiev, M. Z. i dr. (1993). Tatarskaia grammatika [Tatar Grammar]. T.II. Morfologiia. 397 p. Kazan', Akademiia nauk Tatarstana. (In Russian)

Zəinullin, M. V. (2002). Khaz̧erge bashкort az̧əbi tele: morfologiia [Modern Bashkir Literary Language: Morphology]. 388 p. Өfe, BDU. (In Bashkir) 
Sources

Bashкort shigriate korpusy [The Corpus of Bashkir

Poetry]. URL: http://web-corpora.net/bashcorpus/ search/ (accessed: 05.09.2019)
Tatar teleney iazma korpusy [The Written Corpus of the Tatar Language]. URL: http://corpus.tatfolk.ru/ index_tt.php (accessed: 05.09.2019)

Chăvash chĕlkhin ikçlhellĕ sppçi [The Bilingual Corpus of the Chuvash Language]. URL: http://corpus.chv.su/ (accessed: 05.09.2019)

\title{
ТАТАР, БАШКОРТ ҺӘМ ЧУВАШ ТЕЛЛӘРЕНЕН ТАРТЫМ КОНСТРУКЦИЯЛӘРЕНДӘ І ҺӘМ II ЗАТ ТАРТЫМ КУШЫМЧАЛАРЫНЫН КУЛЛАНЫЛУ ЕШЛЫГЫ
}

\author{
Хисияма Юто, \\ Япония, 183-8534, Токио ш., Асахи-тё, Футю-си, 3-11-1, \\ boltwatts@gmail.com. \\ Гүзәл Әмировна Нәбиуллина, \\ Казан федераль университеты, \\ Россия, 420008, Казан ш., Кремль ур., 18 нче йорт, \\ guzelnab2@yandex.ru.
}

\begin{abstract}
Тартым - төрки телләр өчен хас үзенчәлекле грамматик категория. Билгеле булганча, кайбер төрки телләрнең, шул исәптән, татар, башкорт һәм чуваш телләренең тартым конструкцияләрендә иялек килешендәге зат алмашлыгы (I яки II зат) булган очракта, исемгә тартым кушымчасы ялганырга да, ялганмаска да мөмкин: тат. минем дәфтәр(ем), синең дәфтәр (ең), безнең дәфтәр (ебез), сезнең дәфтәр (егез).

Әлеге хезмәттә төп максат итеп, тартым кушымчасының төрки телләрдә, аерым алганда, татар, башкорт һәм чуваш телләрендә кулланылыш ешлыгын анализлау мәсьәләсе куелды. Тикшеренүләрдән күренгәнчә, өч телдә дә тартым кушымчаларының кулланылу ешлыгы, зат hәм санга карап аерылып тора: өч телдә дә I зат күплек сан тартым кушымчасы иң сирәк, ә II зат берлек сан тартым кушымчасы иң еш очрый. Безнең карашка, моңа ике фактор тәэсир итә: 1) зат алмашлыгы белдергән затның күплеге; 2) тартым кушымчасының озынлыгы.
\end{abstract}

Төп төшенчәләр: татар теле, башкорт теле, чуваш теле, тартым категориясе, тартым кушымчалары.

Тартым - төрки телләр өчен хас үзенчәлекле грамматик категория. Кагыйдә буларак, бу категория предметның нинди дә булса затка караганлыгын белдерә. Аның тартым кушымчалары дип аталган махсус күрсәткечләре бар. Татар телендә, мәсәлән, тартым кушымчалары булып -м/-blм/-eм, - $/$ ыңң/-ең, -сыl/-се/-ыb/-е, -быбыз/-ебез/-быз/-без, ыгыз/-егез/-гыз/-гез, -лары/-ләре/ -нары/-нәре формалары санала. Билгеле булганча, кайбер төрки телләрнең, шул исәптән татар, башкорт һәм чуваш телләренең тартым конструкцияләрендә иялек килешендәге зат алмашлыгы (I яки II зат) булган очракта, исемгә тартым кушымчасы ялганырга да, ялганмаска да мөмкин: тат. минем дәфтәр(ем), синен дәфтәр(ең), безнең дәфтәр(ебез), сезнең дафтар (егез).
Төрки тел гыйлемендә тартым категориясе турында башлангыч мәгълүматлар XIX гасыр грамматикаларында бирелә. XX гасыр - XXI гасыр башында язылган төрки грамматикаларда, фәнни хезмәтләрдә тартым, аның формалары, ялгану үзенчәлекләре, мәгънәләре турында жентекләп өйрәнелә. Татар тел белемендә тартымны белдеру юллары Г. Алпаров (1926), В. Н. Хангилдин (1959), 3. М. Вәлиуллина, К. З. Зиннәтуллина, М. А. Сәгыйтов (1972), Д. Г. Тумашева (1978), М. 3. Зәкиев (1993), Ф. М. Хисамова (2006), Ч. М. Харисова (2010) хезмәтләрендә тәфсилләп аңлатыла. В. Хангилдин I, II зат тартым формалары зат алмашлыклары белән генә синтаксик бәйләнешкә керә ала, дип белдерә; иялек килешендәге зат алмашлыгы һәм тартым кушымчалы исем белән ясалган калыпларда аерылмышның кушымчалары кыскартылып 
сөйләнелүенә дә игътибар итә [Хангилдин, б. 80]. В. Хангилдин искәртеп үткәнчә, III зат тартым кушымчалары, I, II зат тартымнан аермалы буларак, затка да, заттан башка предметка да карый, нәтижәдә, III зат тартым формасының төшенчәсе киң һәм билгесез булганга, ул һәрвакыт билгеләнергә тиеш, шуңа күрә аның кушымчасын hәм аергычын кыскартылып куллану очраклары аз [Хангилдин, б 80, б. 81].

3. М. Вәлиуллина, К. З. Зиннәтуллина, М. А. Сәгыйтов төзегән грамматикада тартымның I həм II затлары, предметның яки затның тик затка гына (I hәм II затка) караганлыгын белдереп, өч төрдә (формада) кулланылуы күрсәтелә [Вәлиуллин, Зиннәтуллина, Сәгыйтов, б. 53]. III затны кушымчадан башка белдереп булмавы (аналитик формада), аның, нигездә, зат алмашлыгы яки исем белән ачыкланып килүе аңлатыла, нәтижәдә, аналитик ысул кулланылмавы һәм синтетик ысул да сирәк очравы искәртелә [Вәлиуллина, Зиннәтуллина, Сәгыйтов, б. 53].

Д. Г. Тумашеваның хезмәтендә тартымны белдерү ысуллары аерым күрсәтелмәсә дә, исемгә ялганып килгән тартым кушымчаларының затка караганлыгын белдерүе аңлатыла. Галимә, тартым мәгънәсенең беренче һәм икенче затта аерым сүз белән дә белдерергә мөмкин булуын (минем китап, синең китап, безнең бакча, сезнең бакча) искәртеп, аналитик формага да аерым игътибар итә [Тумашева, б. 46].

M. 3. Зәкиев тарафыннан төзелгән грамматикаларда тартым формалары ачык күрсәтелә һәм һәрбер форманың үзенчәлекләренә дә игътибар ителә. I hәм II зат тартым формаларын белдергән өч ысул күрсәтелә: синтетик ысул, аналитик ысул, һәм аналитик-синтетик ысул [Закиев, б. 32, 33]. һәрбер ысулның кулланылыш үзенчәлекләренә килгәндә, беренче (синтетик) ысул сөйләм телендә дә, язма телдә дә якынча бер дәрәжәдә кулланылса, икенче (аналитик) ысул күбрәк сөйләм теленә, өченче (аналитик-синтетик) ысул күбрәк язма телгә каравы аңлатыла. Галим фикеренчә, өченче ысулга эмоциональлек (хис-тойгы) төсмере хас һәм тартымлы тезмәдәге сүзләрнең урыннарын алыштыру эмоциональлек төсмерен көчәйтә [Закиев, б. 32, 33]. III зат тартым формасына килгәндә, ике ысул: синтетик һәм аналитиксинтетик ысуллар кулланыла, һәм синтетик ысул кулланылган очракта, предметның кемгә (яки нәрсәгә) караганлыгы сөйләмдә ачыклана дип искәртелә [Закиев, б. 33].

Ф. М. Хисамова [Хисамова, б. 101, 102], Ч. М. Харисова хезмәтләрендә дә [Харисова, б. 20-21] тартым мәгънәсен белдерүнең өч структур тибы: синтетик, аналитик-синтетик hәм аналитик ысуллар билгеләнә. I hәм II зат тартым формалары өч типта кулланылса, хәзерге татар әдәби телендә III зат тартым кушымчасы төшеп калу әдәби нормага туры килмәве искәртелә [Харисова, б. 20-21].

Башкорт тел белемендә тартымны белдерү юллары Н. К. Дмитриев (1948), А. А. Юлдашев (1981), М. В. Зәйнуллин (2002) h. б. хезмәтләрендә жентекле тикшерелгән. Н. К. Дмитриев, тартымның төп тибыннан (am-blм, $a m$-blң, $a m$-bl h.б.) тыш, шул ук категорияне белдерә торган яңадан ике тип (минем атым həм hинең am) булуын искәртеп, жентекле аңлатма биргән. Ул тартымның икенче тибын «морфологик-синтаксик тип» (минең атымм), өченче тибын «синтаксик тип»(минең ат) дип атап, үзенең структурасы белән тартымның русча һәм алманча бирелеш формасына (мой конь, mein Pferd) якынрак торуын искәртә [Дмитриев, б. 58]. Автор бу типларның кулланылыш активлыгы мәсьәләсе грамматика өлкәсенә генә түгел, стилистика өлкәсенә дә каравын билгели. Н. К. Дмитриев фикеренчә, amblм формасында төп мәгънәви басым am сүзенә төшә, минең атым сүзтезмәсендә «минекелек» төшенчәсенең кабатлап кулланылуы бу типка билгеле дәрәжәдә хистойгы өсти [Дмитриев, б. 58]. Минең ат формасы VIII гасыр төрки язма истәлекләрдә очрый, шуңа күрә бу форманы рус теле йогынтысында ясалган форма дип исәпләү дөрес түгел дип искәртә галим [Дмитриев, б. 58].

А. А. Юлдашев (1981) хезмәтендә тартымны белдерә торган ике ысул күрсәтелә: I hәм II затта тартым иялек килешендәге зат алмашлыгы hәм тартым кушымчасы белән белдерелә: минең илем, һинең илең; тартым төшенчәсе лексик-синтаксик ысул белән, ягъни иялек килешендәге зат алмашлыклары белән дә белдерелә: минең малай, һинең малай, без̧зең малай, hез̧зең малай [Юлдашев, б. 123]. Тартым кушымчалы исемнең иялек килешендәге зат алмашлыгы белән бергә кулланылуы, предметның шул затныкы икәненә басым ясап, хис-тойгы барлыкка китерә дип аңлатыла, дәлил буларак түбәндәге үрнәкләр бирелә: Был күл минең һарайым, Көн дә коштай койонам 
(фольк.); Күккә ашкан Уралым, - Минең изге төйогем, hез̧зе һөйд йөрәгем (С.Юлаев). [Юлдашев, б. 123]. III зат тартым формасы, I həм II зат тартымнан аермалы буларак, иясен белдергән исем булу-булмауга карамастан, hәрвакыт тартым кушымчасы белән төзелүе искәртелә: уның amahbl, уларзың атаһbl... [Юлдашев, б. 123]. Бу хезмәттә дә берлек сандагы I hәм II зат тартымлы тезелмәләрдә сүз тәртибе үзгәру эмоциональлеккә йогынты ясавына игътибар ителә: Йөрәккәйем минең әллә нишләй, Асып карар инем, аскыс юк (фольк.) [Юлдашев, б. 123].

М. В. Зәйнуллинның 2002 нче елда төзелгән грамматикасында исемнәрдә тартым формаларының төп өч төре булуы бәян ителә: исемнәргә кушымчалар кушылып ясалган төрне «морфологик төр»(китаб-ылм, китаб-ың, китаб-ьl; алма-бызз, алма-вызз, алма-лары); ия булучыны белдергән зат алмашлыгыннан һәм ия булынучыны белдергән тартым кушымчалы исемнән төзелгән төрне «морфологиксинтаксик төр» (минең китаб-ымм, һинең китабың, уның китаб-ыр; без̧зең алма-быз, һез̧зең алма-выз, уларзың алма-лары); ия булучыны белдергән зат алмашлыкларының иялек килеше кушымчалы хәлдә, ия булынучы предметны белдергән исемнең кушымчасыз хәлдә кулланылуыннан ясалган төрне «синтаксик төр» (минең китап, һинең китап, без̧зең китап, hез̧зеең китаn) дип атый [Зәйнуллин, б. 21].

Чуваш телендә тартымны белдерү юллары J. Krueger (1961), Л. П. Сергеев, Е. А. Андреева, В. И. Котлеев (2012) хезмәтләрендә аңлатыла. Ј. Krueger язганча, чуваш телендә тартымны (personal possession) белдерүче өч ысул бар [Krueger, б. 113, 116]. Беренче ысул - инглиз теленең «my, our, your...» сүзләренә туры килгән, иялек килешле зат алмашлыклары белән белдерү ысулы: манӑн лаша (минем ат), санӑн лаша (синең ат), унӑн лаши (аның аты), пирён лаша (безнең ат), сирён лаша (сезнең ат), вёсен лаши (аларның аты) [Krueger, б. 113]. J. Krueger фикеренчә, тартым төшенчәсен белдерүнең әлеге ысулы чуваш телендә киң кулланыла. Галим башка төрки телләрдә очраган тагын бер ысулга игътибар юнәлтеп, ия булучының кем икәнен белдерү өчен, махсус кушымча куллану ысулын күрсәтә. Мәсәлән: ыввӑл-ӑм (ул-ым), ьввӑл-у (ул-ың), ьөвӑл-ё (ул-ы), ьввӑл-ӑмӑр (ул-ыбыз), ьввӑл-ӑр (ул-ыгыз), ьввӑл-ӗ (ул-ы) [Krueger, б. 116]. Автор, предметнең кемнеке икәнен ачыклап әйтергә кирәк булганда, өстәге ике ысул бергә кулланыла дип аңлата. Бу ысул, башлыча, инглиз теленең «Our son did this, but their son did that.» жөмләсендәге кебек, аерым басым ясау өчен кулланыла: манӑн ьввӑл-ӑм (минем ул-ым), санӑн ыввӑл-y (синең ул-ың), унӑн ыввӑл-ӗ (аның ул-ы), пирӗн ывӑл-ӑмӑр (безнең ул-ыбыз), сирӗн ывӑл-ӑр (сезнең ул-ыгыз), вӗсен ыввӑл-ӗ (аларның ул-ы) [Krueger, б. 113, 116]. J. Kruegerның сүзләренчә, хәзерге чуваш телендә I həм II зат күплектә аналитик конструкция еш кулланыла. Мәсәлән, вьвӑл-ӑмӑр урынына пирӗн ьввӑл, ьввӑл-ӑр урынына сирён вьвӑл-у кулланыла [Krueger,б. 118].

Л. П. Сергеев хезмәтендә предметның кайсы затка каравы түбәндәге ике ысул белән белдерелә дип аңлатыла:

1) исем алдында, кемнеке икәнен белдерүче сүзне, ягъни зат алмашлыкларын (манӑн, пирён, санӑн, сирён, унӑн, вёсен) куллану (синтактик ысул). Мәсәлән: манӑн ручка (минем ручка), пирён ручка (безнең ручка), сирӗн кӗнеке (сезнең китап), унӑн ручки (аның ручкасы), вёсен кеенеки (аларның китабы);

2) предметның кемнеке икәнен морфологик ысул, ягъни махсус кушымчалар белән дә белдереп була. Мондый кушымчалар тартым кушымчалары (чув. камӑнлӑх аффиксӗсем) дип атала. Мәсәлән: сётел-ём (өстәл-ем), сётел-й (өстәл-ең), сётел-ё (өстәл-е) [Сергеев, б. 266, 267].

Л. П. Сергеев аңлатуынча, I hәм II зат тартым кушымчалары хәзерге чуваш телендә сирәк кулланыла: предметның I затка каравын кушымчасыз, контекст белән белдерергә мөмкин. Мәсәлән: кус курмасть (күз күрми) үрнәгендә, күзнең I затка каравы контексттан аңлашыла. Шуңа бәйле рәвештә I зат тартым кушымчалары сөйләмдә сирәгрәк очрый дип аңлата галим [Сергеев, б. 270]. Предметның кемгә каравы катнаш ысул белән дә белдерелергә мөмкин булып (санӑн (хӑвӑн) кёнек-ÿ (синең (үзеңнең) китаб-ың), пирён (хамӑрӑн) учител-ёмёр (безнең (үзебезнең) укытучы-быз)), мондый тезелмәләрнең матур әдәбиятта күбрәк очрап, сөйләм теленә бик үк характерлы булмавы искәртелә [Сергеев, б. 272]. III зат башка затлардан аермалы буларак, hәрвакыт тартым кушымчасын ала: (унӑн) тетрач-ӗ ((аның) дәфтәр-е), (вёсен) пуррч-ӗ ((аларның) йорт-ы), (хӑйӗн) лаш-и ((үзенең) аты) [Сергеев, б. 272].

Күренгәнчә, татар, башкорт һәм чуваш грамматикаларында тартым конструкцияләре жентекләп тикшерелгән. Тюрколог галимнәр 
тартымлы тезелмәләрнең, нигездә - язма телгә, тартымсыз тезелмәләрнең сөйләм теленә характерлы булуын дәлиллиләр. Теоретик тикшеренүләрдән күренгәнчә, тартым категориясе, аның асылы, кулланылышы, типлары төрки тел белемендә шактый өйрәнелгән дияргә була. Шулай да ачыкланып бетмәгән кайбер сораулар, әйтик, тартым категориясенең аерым структур типларына бәйле кулланылыш ешлыгы, кулланылыш парадигмасы, грамматик табигате, стилистик үзенчәлекләре бүгенге көндә тиешле дәрәжәдә ачыкланып беткән дип әйтә алмыйбыз. Шуны истә тотып, әлеге хезмәттә төп максат итеп тартым кушымчасының төрки телләрдә, аерым алганда, татар, башкорт һәм чуваш телләрендә кулланылыш ешлыгын анализлау мәсьәләсе куелды. Әлеге фәнни мәкалә кысаларында татар, башкорт һәм чуваш телләрендә I яки II зат тартым формаларын тикшерү күздә тотыла. Тикшерену объекты итеп татар, башкорт һәм чуваш телләренең иялек килешендәге I яки II зат алмашлыгы белән тартымлы яки тартымсыз исемнән торган сүзтезмәләр (тартым конструкцияләре) алынды. Тартым кушымчаларының кулланылу ешлыгын тикшерүдә статистик ысул, нәтижәләрне анализлауда чагыштырма hәм тасвирлама ысуллар файдаланылды. Тикшеренүдә түбәндәге онлайн корпуслардан файдаландык:

1) Татар теленең язма корпусы. Бу сайтта 356 миллионнан артык сүз теркәлгән [http://corpus.tatfolk.ru/index_tt.php].

2) Башкорт шиғриәте корпусы. 1 миллионнан артык сүз теркәлгән. 500 мең чамасы шигъри юл, 101 шагыйрьнең 13 меңнән артык шигырен Ү3 эченә ала [http://webcorpora.net/bashcorpus/search/].

3) Чӑваш чӗлхин икчӗлхеллӗ с̧йпс̧и (Двуязычный корпус чувашского языка). 1 миллионнан артык сүз теркәлгән. Башлыча газета-журнал мәкаләләрен һәм дини эчтәлекле язмаларны үз эченә ала [http://corpus.chv.su/].

Әлеге корпуслар нигезендә ясалган анализ нәтижәләре буенча татар, башкорт һәм чуваш телләрендәге I hәм II зат тартым кушымчаларының кулланылу ешлыгына бәйле гомуми тенденцияләр түбәндәгеләр:

1) «Татар теленең язма корпусы»ннан I hәм II зат алмашлыгына 250 шәр, барлыгы 1000 тартым конструкциясен туплап, тартымлы һәм тартымсыз конструкцияләрнең кулланылыш ешлыгы буенча шундый нәтижәләр алынды:
I зат берлек

тартымсыз

тартымлы

I зат күплек

$91(36.4 \%)$

$159(63.6 \%)$

II зат берлек

$209(83.6 \%)$

$41(16.4 \%)$

II зат күплек

$51(20.4 \%)$

$199(79.6 \%)$

$134(53.6 \%) \quad 116(46.4 \%)$

2) «Башкорт шиғриәте корпусы»ннанI hәм II зат алмашлыгына 50 шәр, барлыгы 200 тартымлы тезелмәләрне туплап, кулланылыш ешлыгы буенча шундый нәтижәләр алынды:

$\begin{array}{lcc} & \text { тартымсыз } & \text { тартымлы } \\ \text { I зат берлек } & 20(40.0 \%) & \mathbf{3 0}(\mathbf{6 4 . 0 \%}) \\ \text { I зат күплек } & \mathbf{4 5 ( 9 0 . 0 \% )} & 5(10.0 \%) \\ \text { II зат берлек } & 8(16.0 \%) & \mathbf{4 2}(\mathbf{8 4 . 0 \% )} \\ \text { II зат күплек } & \mathbf{3 3 ( 6 6 . 0 \% )} & 17(34.0 \%)\end{array}$

3) «Чӑваш чӗлхин икчӗлхеллӗ с̧йпс̧и (Двуязычный корпус чувашского языка)» корпусыннан I hәм II зат алмашлыгына 50 шәр, барлыгы 200 тартым конструкциясен туплап, кулланылыш ешлыгы шундый нәтижәләрдән гыйбарәт булды:

$\begin{array}{lcc} & \text { тартымсыз } & \text { тартымлы } \\ \text { I зат берлек } & \mathbf{4 2}(\mathbf{8 4 . 0 \% )} & 8(16.0 \%) \\ \text { I зат күплек } & \mathbf{4 9 ( 9 8 . 0 \% )} & \mathbf{1 ( 2 . 0 \% )} \\ \text { II зат берлек } & 13(26.0 \%) & \mathbf{3 7}(\mathbf{7 4 . 0 \% )} \\ \text { II зат күплек } & \mathbf{3 1 ( 6 2 . 0 \% )} & \mathbf{1 9 ( 3 8 . 0 \% )}\end{array}$

Корпуслардан алынган материалларны анализлау нәтижәләреннән аңлашылганча, татар hәм башкорт телләрендә иялек килешендәге зат алмашлыгының төренә карап, ике форманың кулланылыш ешлыгында аерма күзәтелде. Ике телдә дә берлек сан зат алмашлыгы белән кулланылган конструкцияләрдә аналитик форма аналитиксинтетик формага караганда азрак очрады. Киресенчә, күплек сан зат алмашлыклы белән кулланылган конструкцияләрдә аналитик форма аналитик-синтетик формага караганда күбрәк теркәлде. Моның төп сәбәбен, күплек зат тартым кушымчаларының чагыштырмача озынрак булып, экономияләү аркылы ешрак кыскартылуга дучар булуы белән аңлатырга мөмкиндер. Ике затны үзара чагыштырганда, аналитик форма II затка караганда I затта активрак икәнлеге дә аңлашылды. Стильгә карап ике форманың кулланылу ешлыгында аермалар булса да, югарыда әйтелгән гомуми тенденцияләрдә зур аермалар күзәтелмәде. Безнеңчә, ике форманың кулланылыш ешлыгын грамматикаларда аңлатылган стиль 
яки эмоциональлек белән генә билгеләп булмый. Ул зат алмашлыгының, тартым конструкциясенең һәм тартым конструкциясендәге исемнең төренә карап та үзгәрә дип әйтергә мөмкин. Күренгәнчә, өч телдә дә тартым кушымчаларының кулланылу ешлыгы, зат һәм санга карап аерылып тора һәм өч телдә дә I зат күплек сан тартым кушымчасы иң сирәк, ә II зат берлек сан тартым кушымчасы иң еш очрый. Өч телдә уртак тенденцияләр күзәтелүе игътибарга лаек.

Нәтижәләрдән чыгып, тартым кушымчаларының кулланылыш ешлыгына түбәндәге ике фактор тәэсир итә дип әйтергә мөмкин:

1) Зат алмашлыгы белдергән затның күплеге. Өч телдә дә II зат күплек сан алмашлыгы (тат. сез, баш. hез, чув. эсир) бердәнбер затны гына белдерергә мөмкин. I зат күплек сан алмашлыгы (тат. без, баш. без, чув. эпир) исә, һәрвакыт икедән күбрәк кешене белдерә. Шунлыктан, зат алмашлыгы белдергән зат күплеккә ия булса, тартым кушымчасының кулланылу ешлыгы сирәк булырга мөмкин. II зат күплек сан тартым кушымчасының кулланылу ешлыгы да берлек сан тартым кушымчаларына караганда сирәгрәк. Бу фактор исә чуваш теленә кагылмый. Чөнки чуваш телендә I зат берлек сан тартым кушымчасының кулланылу ешлыгы II зат күплек сан тартым кушымчасыннан сирәгрәк.

2) Тартым кушымчасының озынлыгы. Чагыштырмача озын тартым кушымчалары, экономия принцибыннан чыгып, ешрак төшеп калырга мөмкин. Татар һәм башкорт телләрендә күплек сан тартым кушымчалары (тат. -(bl)былз/-(e)без, -(bl)гыл/-(e)гез; баш. (bl)бызы/-(e)без,, -(bl)zызз/-(e)гез ) берлек сан тартым кушымчаларына $\left(-(b l)_{\mathcal{M}} /-(e)_{\mathcal{M}}, \quad-(b l)_{y /-}\right.$ (е)ң) караганда озынрак. Чуваш телендә I зат күплек тартым кушымчасы (-(ă)мӑр/-(ё)мёр) башка тартым кушымчаларына $\left(-(\breve{a})_{\mathcal{M}} /-(\breve{e})_{\mathcal{M}},-y /-\right.$ $\ddot{y,} \quad-(\breve{a}) p /-(\breve{e}) p) \quad$ караганда озынрак. Чуваш телендә кыска тартым кушымчалары арасында нигә II зат берлек сан тартым кушымчасы сирәк очрый дигән сорау хәл ителми кала.

Нәтижә ясап әйткәндә, өч телдә дә тартым кушымчаларының кулланылыш ешлыгы, зат һәм санга карап аерылып тора: өч телдә дә I зат күплек сан тартым кушымчасы иң сирәк, ә II зат берлек сан тартым кушымчасы иң еш очрый. Безнең карашка, моңа ике фактор тәэсир итә: 1) зат алмашлыгы белдергән затның күплеге; 2) тартым кушымчасының озынлыгы. Болардан тыш, башка сәбәпләр дә булырга мөмкин. Мондый сорауларны ачыклау һәм әлеге тенденциянең башка төрки телләрдә дә чагылышын тикшерү алдагы бурычыбыз булып тора.

\section{Әдәбият}

Вәлиуллина 3. М., Зиннәтуллина К. 3., Сәгыйтов $M . A$. Хәзерге татар әдәби теле морфологиясе. Казан: КДПИ, 1972. 206 б.

Зәйнуллин М. В. Хәзерге башкорт әзəби теле: морфология. Өфө: БДУ, 2002. 388 б.

Тумашева Д. Г. Хәзерге татар әдәби теле: Морфология. Казан: Татарстан китап нәшрияты, 1978. 221 б.

Хангилдин B. H. Татар теле грамматикасы. Казан: Татарстан китап нәшрияты, 1959. 642 б.

Харисова Ч. М. Хәзерге татар әдәби теле морфологиясеннән лекцияләр. Казан: Татар дәүләт гуманитар-педагогика университеты, 2010. 128 б.

Хисамова $\Phi$. M. Татар теле морфологиясе. Казан: Мәгариф нәшрияты, 2006. 335 б.

Дмитриев Н. К. Грамматика башкирского языка. AH CCCP. М., 1948. 276 c.

Закиев М. 3. и др. Татарская грамматика. Т. II. Морфология. Казань: Академия наук Татарстана, 1993. $397 \mathrm{c.}$

Юлдашев A. A. Грамматика современного башкирского литературного языка. М.: Наука, 1981. 495 c.

Сергеев Л. П., Андреева Е. А., Котлеев В. И. Чӑваш чӗлхи: чӑваш филологи факультечӗн студенчӗсем валли хатёрленӗ вёрену” кёнеки. Шупашкар: Чӑваш кӗнеке изд-ви, 2012. 431 с.

HishiyamaY. Possessive person markings in Tatar possessive noun phrases. Language, area and culture studies [25]. Tokyo: Tokyo University of Foreign Studies, 2019. 93-113 pp.

Krueger J. Chuvash Manual. Introduction, Grammar, Reader, and Vocabulary. Indiana University Publications, Uralic and Altaic Series 7.The Hague: Mouton, 1961.271pp.

\section{Чыганаклар}

Башкорт шиғриәте корпусы. Режим доступа: http://web-corpora.net/bashcorpus/search/. (Дата обращения: 05.09.2019)

Татар теленең язма корпусы. Режим доступа: http://corpus.tatfolk.ru/index_tt.php. (Дата обращения: 05.09.2019)

Чӑваш чӗлхин икчӗлхеллӗ суйпси. Режим доступа: http:/corpus.chv.su/. (Дата обращения: 05.09.2019) 


\section{ЧАСТОТНОСТЬ ИСПОЛЬЗОВАНИЯ АФФИКСОВ ПРИНАДЛЕЖНОСТИ 1 И 2 ЛИЦА В ТАТАРСКОМ, БАШКИРСКОМ И ЧУВАШСКОМ ЯЗЫКАХ}

Хисияма Юто, Япония, 183-8534, Токио ш., Асахи-тё, Футю-си, 3-11-1, boltwatts@gmail.com.

Гузель Амировна Набиуллина, Казанский федеральный университет, Россия, 420008, г. Казань, ул. Кремлевская, д. 18, guzelnab2@yandex.ru.

Многие тюркские языки имеют категорию принадлежности. Однако, как указывается в тюркологических исследованиях, в некоторых тюркских языках, включая татарский, башкирский и чувашский, аффикс принадлежности необязателен, если конструкция принадлежности включает местоимение I или II лица: минем дәфтәр (ем), синең дәфтәр (ец), безнең дәфтәр (ебез), сезнен дәфтәр (егез).

Целью нашего исследования является определение частотности употребления категории принадлежности на материале татарского, башкирского и чувашского языков. В работе доказывается, что не только в татарском, но и в башкирском, и чувашском языках аффиксы принадлежности варьируются в зависимости от лица и числа. Аффикс принадлежности I лица множественного числа встречается чаще всего, а аффикс принадлежности II лица единственного числа имеет самую низкую частотность. На наш взгляд, на это влияют два фактора: 1) обозначение личным местоимением более одного человека, 2) длина аффикса принадлежности.

Ключевые слова: татарский язык, башкирский язык, чувашский язык, категория принадлежности, аффикс принадлежности. 